\title{
SISTEM INFORMASI GEOGRAFIS PEMETAAN KOMODITAS PERTANIAN BERBASIS WEB DI KABUPATEN ACEH UTARA
}

\author{
Mochamad Ari Saptari ${ }^{1 *}$, Trisna $^{2}$ dan Muhammad Zakaria ${ }^{2}$ \\ ${ }^{1}$ Jurusan Sistem Informasi, Fakultas Teknik, Universitas Malikussaleh, Aceh, Indonesia \\ 2Jurusan Teknik Industri, Fakultas Teknik, Universitas Malikussaleh, Aceh, Indonesia \\ ${ }^{*}$ Corresponding Author: moch.ari@unimal.ac.id
}

\begin{abstract}
Abstrak - Aceh Utara merupakan salah satu kabupaten di Provinsi Aceh yang merupakan daerah agraris yang sangat potensial dalam bidang pertanian dan perkebunan. Sektor pertanian di Kabupaten Aceh Utara merupakan sektor strategis yang mempunyai keterkaitan erat dengan pengurangan kemiskinan, membuka lapangan pekerjaan, usaha membangun ketahanan pangan, memproduksi dan membeli pangan, usaha pelestarian lingkungan, serta basis pembangunan ekonomi daerah. Tujuan dari penelitian ini untuk melakukan pemetaan komoditas pertanian di Aceh Utara dengan sistem informasi geografis yang berbasis website. Pemanfaatan teknologi sistem informasi geografis akan sangat mempengaruhi kecepatan perencanaan, antisipasi, langkah strategis serta upaya peningkatan potensi dan produksi komoditas unggulan di di Aceh Utara. Sistem informasi geografis pemetaan komoditas ini dirancang dengan berbasis web sehingga dapat memberi informasi yang akurat tentang potensi pertanian. Hal ini dapat membantu dinas pertanian dan tanaman pangan dalam membuat kebijakan yang cepat dan tepat. Langkah-langkah penelitian ini meliputi: identifikasi kebutuhan dan permasalahan, pengambilan data komoditas pertanian, pengolahan data, pengembangan sistem informasi geografis, pengujian sistem, dan validasi. Capaian yang diharapkan dari penelitian ini adalah berupa publikasi pada jurnal nasional dan website sistem informasi geografis.
\end{abstract}

Kata Kunci: Sistem informasi geografis, komoditas pertanian, pemetaan, website.

\section{Pendahuluan}

Perkembangan teknologi di era globalisasi saat ini berlangsung sangat cepat. Teknologi informasi sudah menjadi hal yang sangat lumrah dan sebuah keharusan dalam segala aspek kehidupan. Data dan informasi yang diperlukan tentu harus mudah diakses oleh berbagai pihak yang berkepentingan. Saat ini, Sistem Informasi Geografis (SIG) mengalami perkembangan yang berarti seiring kemajuan teknologi informasi [3]. SIG merupakan sistem informasi berbasis komputer yang menggabungkan antara unsur peta (geografis) dan informasinya tentang peta tersebut (data atribut) yang dirancang untuk mendapatkan, mengolah, memanipulasi, analisa, memperagakan dan menampilkan data spasial untuk menyelesaikan perencanaan, mengolah dan meneliti permasalahan.

Kabupaten Aceh Utara merupakan salah satu kabupaten di Provinsi Aceh yang mempunyai daerah agraris yang sangat potensial dalam bidang pertanian dan perkebunan. Sektor pertanian di Kabupaten Aceh Utara merupakan sektor strategis yang mempunyai keterkaitan erat dengan pengurangan kemiskinan, upaya mengatasi pengangguran, usaha membangun ketahanan pangan, memproduksi dan membeli pangan, usaha pelestarian lingkungan dan basis pembangunan ekonomi daerah.

Dalam dunia yang serba digital sekarang ini, ditambah lagi teknologi yang terus berkembang, penerapan aplikasi teknologi dalam berbagai bidang pun terus dilakukan, tidak terkecuali dalam sektor pertanian yang merupakan sektor perekonomian utama di Indonesia mengingat sebagian besar penduduknya menggantungkan hidup dalam dunia pertanian.

Saat ini, pengelolaan data komoditas pertanian di Dinas Pertanian dan Tanaman Pangan Aceh Utara masih bersifat konvensional dengan menggunakan dokumen kertas, file bersifat offline serta peta analog untuk menampilkan persebaran komoditas pertanian. Hal ini 
menimbulkan permasalahan bagi masyarakat umum maupun instansi dalam mengakses pemetaan komoditas pertanian yang ada. Kendala lain ditemukan masih kesulitan dalam mengidentifikasi potensi komoditas pertanian di setiap kecamatan. Untuk mengatasi masalah tersebut diperlukan suatu peta digital berbasis Sistem Informasi Geografis berbasis Web yang lebih efektif dalam memberikan informasi baik berupa spasial maupun non spasial yang ada di Kabupaten Aceh Utara. Sistem informasi geografis merupakan cara pengelolaan data yang memiliki informasi spasial (bereferensi keruangan) yang dirancang untuk bekerja dengan data yang berkoordinat geografi. Sistem ini dapat digunakan sebagai dasar pengambilan keputusan dalam mengelola komoditas pertanian di Aceh Utara.

\section{Tinjauan Pustaka}

\subsection{Konsep Dasar Sistem Informasi Geografis}

Menurut [6], peta digital menyimpan dua jenis informasi dasar yaitu :

1. Informasi spasial yang menjabarkan lokasi dan bentuk dari feature geografi dan hubungan spasial pada feature lainnya.

2. Informasi deskriptif (non spatial) yang berisi keterangan/atribut dari suatu feature.

Adapun jenis-jenis dari feature-feature geografi adalah sebagai berikut :

1. Point/titik adalah lokasi diskrit, biasanya digambarkan sebagai simbol atau label. Point biasanya juga digunakan untuk menggambarkan lokasi yang tidak mempunyai luasan seperti titik tinggi atau puncak gunung.

2. Line atau arc/garis adalah feature yang dibentuk oleh sekumpulan koordinat yang saling berhubungan.

3. Polygon/luasan (area) adalah feature luasan yang dibentuk dari garis yang tertutup menggambarkan suatu area yang homogen. Biasanya digunakan untuk menggambarkan suatu feature seperti batas Negara, kecamatan, danau dan lain-lain.

Sistem Informasi Geografis (SIG) dapat dapat diuraikan menjadi beberapa subsistem [6], yaitu:

1. Subsistem masukan data (input). Subsistem ini digunakan untuk memasukkan data dan mengubah data asli ke bentuk yang dapat diterima dan dipakai dalam SIG. Semua data dasar geografi diubah dulu menjadi data digital, sebelum dimasukkan ke komputer. Ada dua macam data geografi, yaitu data spasial dan nonspasial. Data spasial (keruangan), yaitu data yang menunjukkan ruang, lokasi atau tempat dipermukaan bumi. Data spasial berasal dari peta analog, foto udara dan penginderaan jauh dalam bentuk cetak kertas. Ada 2 macam data spasial yaitu data raster dan data vektor (Budiyanto, 2010). Data non-spasial, yaitu data yang berupa text atau angka ysng menerangkan data spasial atau sebagai dasar untuk menggambarkan data spasial, dari data non-spasial ini nantinya dapat dibentuk data spasial. Data non-spasial disebut juga sebagai atribut yang menjelaskan suatu informasi, data atribut ini diperoleh dari statistic, sensus, catatan lapangan dan tabular (data yang disimpan dalam bentuk tabel) lainnya.

2. Subsistem Manipulasi dan Analisis Data. Subsistem ini menentukan informasi-informasi yang dapat dihasilkan oleh SIG. Subsistem ini juga dapat melakukan manipulasi dan pemodelan data untuk menghasilkan informasi yang diharapkan.

3. Subsistem Penyajian Data (output). Subsistem output data berfungsi menayangkan informasi geografi sebagai hasil analisis data dalam proses SIG. informasi tersebut ditayangkan dalam bentuk peta, tabel, bagan, gambar, grafik dan hasil perhitungan.

4. Pengolahan Data. Subsistem ini mengorganisasikan baik data spasial maupun data atribut ke dalam sebuah basis data sedemikian rupa sehingga mudah dipanggil, di update, dan diedit.

\subsection{Komponen Sistem Informasi Geografis}

Terdapat beberapa komponen utama dalam membangun sebuah Sistem Informasi Geografis [6], yaitu:

1. Perangkat Keras (Hardware). GIS membutuhkan komputer untuk penyimpanan dan pemrosesan data. Ukuran dari sistem komputerisasi bergantung pada tipe SIG itu sendiri. SIG dengan skala yang kecil hanya membutuhkan PC (personal computer) yang kecil dan sebaliknya. Ketika SIG yang di buat berskala besar di perlukan spesifikasi komputer yang besar pula serta host untuk client machine yang mendukung penggunaan multiple user. Hal tersebut disebabkan data yang digunakan dalam SIG baik data vektor maupun data raster penyimpanannya membutuhkan ruang yang besar dan dalam proses analisanya membutuhkan memori yang besar dan prosesor yang cepat. Untuk mengubah peta ke dalam bentuk digital diperlukan hardware yang disebut digitizer.

2. Perangkat Lunak (Software). Dalam pembuatan SIG diperlukan software yang menyediakan fungsi tool yang mampu melakukan penyimpanan data, analisis dan menampilkan informasi geografis. Dengan demikian, elemen yang harus terdapat dalam komponen software SIG adalah:

a. Tool untuk melakukan input dan transformasi data geografis

b. Tool yang mendukung query geografis, analisa dan visualisasi

c. Graphical User Interface (GUI) untuk memudahkan akses pada tool geografi.

3. Data. SIG merupakan perangkat pengelolaan basis data (DBMS = Database Management System) dimana interaksi dengan pemakai dilakukan dengan suatu sistem antar muka dan sistem query dan basis data dibangun untuk aplikasi multiuser. 


\subsection{Website}

Website atau disingkat Web adalah kumpulan halaman yang menampilkan informasi data teks, data gambar, data animasi, suara, video, dan gabungan dari semuanya, baik yang bersifat statis maupun dinamis yang membentuk satu rangkaian bangunan yang saling terkait, dimana masing-masing dihubungkan dengan jaringanjaringan halaman (hyperlink)".

\section{Metodelogi Penelitian}

Langkah-langkah penelitian secara ringkas dalam diagram alir dapat dilihat pada gambar berikut ini [6] :

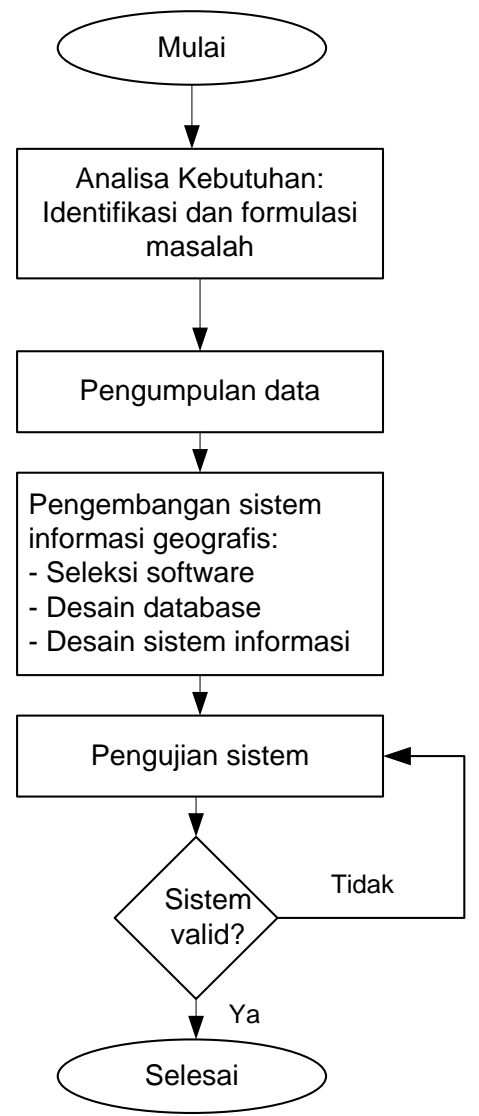

Gambar 1. Diagram Alir Penelitian

Penelitian ini menggunakan dua metode, yaitu survey lapangan dan studi literature. Survey lapangan diperlukan untuk mengetahui secara riil mengenai data pertanian yang ada wilayah kabupaten Aceh utara pada tiap - tiap kecamatannya, selain itu juga untuk dapat langsung mewawancarai para pelaku pasar dalam komoditas pertanian. Studi literatur diperlukan untuk mengetahui kesesuaian antara teori dan kondisi lapangan, agar dapat terarah pada proses penelitiannya.

Setelah dilakukan survey lapangan, maka didapatlah data hasil bumi. Dimana data tersebut dipilah sesuai kebutuhan, data - data tersebut dikelompokkan sesuai dengan wilayah kecamatannya, dan disajikan dalam bentuk tabel.
Sedangkan studi literatur dilakukan melalui buku buku elektronik yang dipublikasikan oleh instansi terkait, yaitu Badan Pusat Statistik (BPS) Aceh Utara [5].

Setelah tahapan tersebut dilewati, maka data - data tersebut disajikan secara online melalui situs web, yang disajikan oleh ESRI sebagai produsen dan penyedia situs pemetaan, dengan nama ArcGIS Online.

\section{Hasil Dan Pembahasan}

\subsection{Peta Wilayah Adm. Kab. Aceh Utara}

Berdasarkan hasil studi literatur dan survey lapangan, didapatkan dasar analisis dan pembahasan sebagai berikut. Kabupaten Aceh Utara membentang dari utara ke selatan yang berbatasan dengan Selat Malaka dan Kota Lhokseumawe di utara, Kabupaten Bireun di barat, di selatan dengan Kabupaten Bener Meuriah, di timur Kabupaten Aceh Timur [9]. Luasnya kurang lebih sekitar $3.237 \mathrm{~km}^{2}$ serta terdapat 27 kecamatan, berikut ini peta administrasinya :

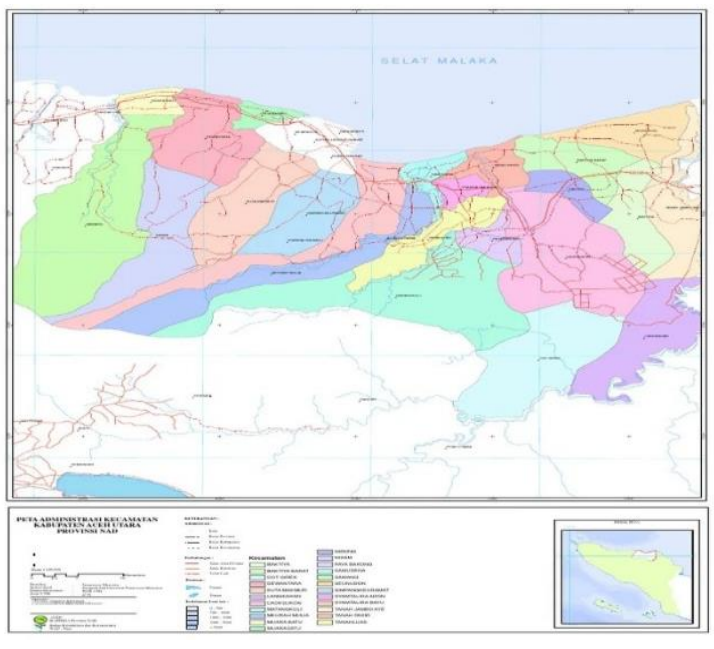

Gambar 2. Wilayah Kab. Aceh Utara

Berdasarkan data dan fakta, hasil bumi Kabupaten Aceh Utara tersebar pada 27 kecamatan, tetapi pada paparan data berikut hanya disajikan pada 3 kecamatan saja. Paparannya sebagai berikut :

\subsection{Kecamatan Baktiya}

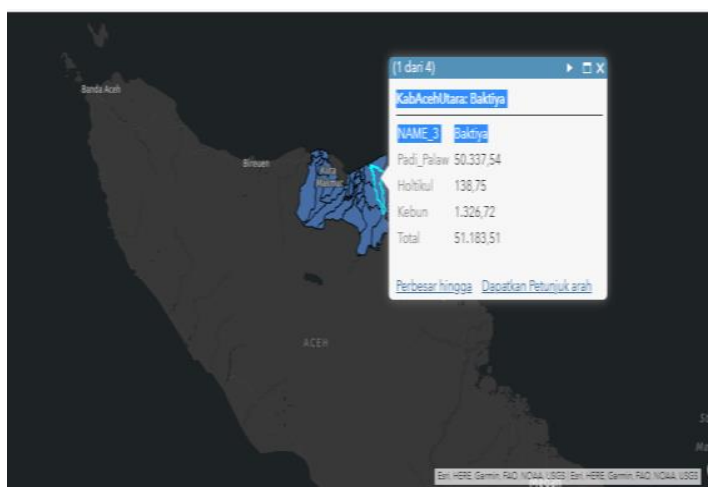

Gambar 3. Data Online Pertanian Kec. Baktiya 
Komoditas unggulan di Kecamatan Baktiya, pada kategori padi dan palawija dengan kapasitas produksi mencapai 50,120.89 ton/th. Sedangkan kategori holtikultura produksi terong dan timun adalah unggulannya, dengan produksi 65.15 ton/th dan 31.20 ton/th. Pada kategori perkebunan rakyat kelapa sawit, pinang, dan kelapa, kapasitas produksinya masing masing adalah sebesar 869.00 ton/th, 206.00 ton/th, dan 174.00 ton/th. Luas lahan produktif berdasarkan data statistik yang dikeluarkan oleh Badan Pusat Statistik Kabupaten Aceh Utara adalah hanya sekitar $1 / 3$ nya saja dari luas wilayah Kecamatan Baktiya, atau sekitar 5.128 Ha (Nursaidah, 2020).

\subsection{Kecamatan Baktiya Barat}

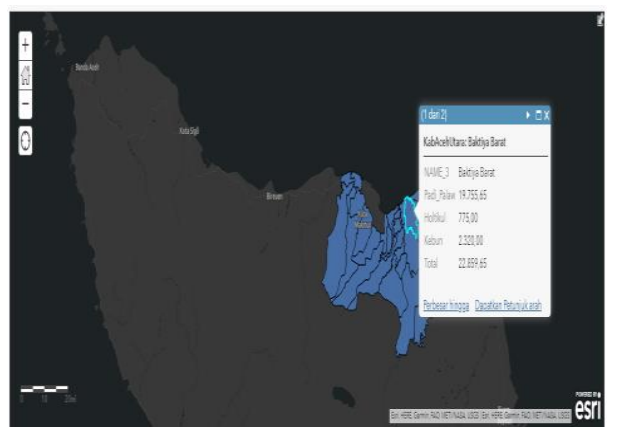

Gambar 3. Data Online Pertanian Kec. Baktiya Barat

Komoditas unggulan pada kecamatan ini adalah padi untuk kategori padi dan palawija, dengan jumlah $16,143.00$ ton/th produksinya, juga jagung dengan kapasitas produksi 3,612.65 ton/th masih pada kategori yang sama. Untuk kategori lainnya yaitu holtikultura, ada pada kangkung dan cabe rawit kapasitas produksinya masing - masing adalah 193.00 ton/th dan 190 ton/th. Sedangkan untuk kategori perkebunan rakyat, kelapa sawit menduduki posisi tertinggi produksinya, dengan jumlah mencapai 1,504.00 ton/th, disusul dengan kelapa 640.00 ton/th pada kategori yang sama. Luas wilayah lahan produktif $2,638 \mathrm{Ha}$, baik lahan teknis maupun tadah hujan, lebih kecil dari kecamatan tetangganya yakni, hanya $1 / 4$ dari luas wilayah keseluruhan yaitu seluas 8.308 H.

\subsection{Kecamatan Banda Baro}

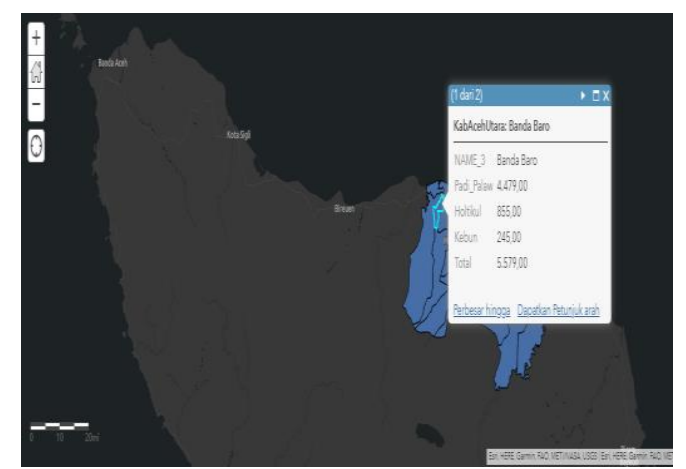

Gambar 3. Data Online Pertanian Kec. Banda Baro
Komoditas unggulan pada kategori pertama adalah padi, dengan jumlah produksi 4,102.00 ton/th, dan kedele pada posisi kedua dengan produksi sebanyak 299.00 ton/th pada kategori yang sama. Selanjutnya adalah hasil bumi jenis holtikultura produksi tertinggi ada pada ketimun dengan jumlah 285.00 ton/th, dan posisi kedua, cabe rawit produksinya mencapai 205.00 ton/th. Sedangkan pada kategori ketiga, yaitu perkebunan rakyat, produksi tertinggi adalah pinang dengan jumlah produksi sebesar 101.00 ton/th disusul dengan kelapa pada posisi kedua yaitu 75 ton/th produksinya.

\subsection{Data Pertanian Kabupaten Aceh Utara}

Tabel 1. Data Pertanian Kab. Aceh Utara pada tiap Kecamatan

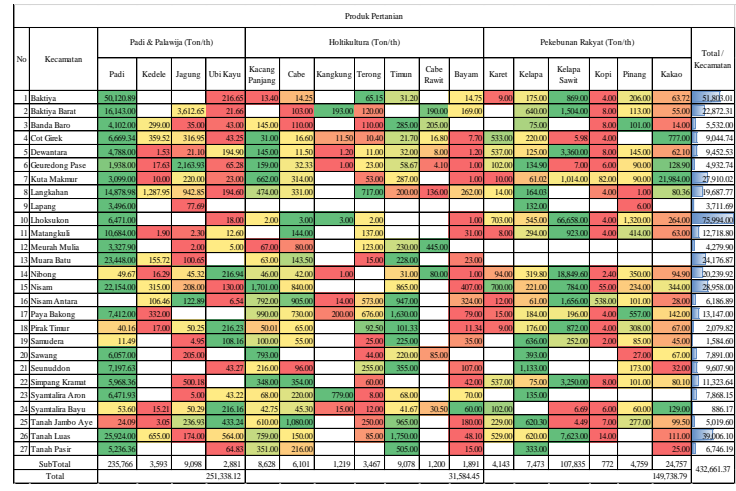

Seperti tampak pada tabel 1 di atas, bahwa komoditas unggulan hasil bumi aceh utara, terdapat pada dua kategori, yaitu, padi dan palawija, serta perkebunan rakyat, untuk kategori pertama komoditas unggulannya adalah padi dengan total produksi mencapai 235,776 ton/th, dan posisi kedua adalah produksi kelapa sawit dengan total produksi 107,835.00 ton/th, terakhir adalah produksi kakao produksi total mencapai $24,757.00$ ton/th. Lahan produktif untuk menghasilkan komoditas komoditas tersebut tersebar ke wilayah pesisir dan perbukitan, dimana wilayah pesisir didominasi oleh komoditas padi dan palawija, sedangkan wilayah perbukitan didominasi perkebunan rakyat. (Nursaidah, 2019).

Luas lahan irigasi dan tadah hujan untuk pertanian padi masing-masingnya seluas 29,188 $\mathrm{Ha}$ untuk lahan irigasi dan 8,058 Ha lahan tadah hujan. Sedangkan luas lahan perkebunan terdiri dari kebun/tegal 42,941 $\mathrm{Ha}$, lading/huma 22,404 $\mathrm{Ha}$, dan lahan tidur seluas $12,715 \mathrm{Ha}$ (Nursaidah, 2019). Luas lahan dan sistem pengairan mempengaruhi produktifitas pertanian aceh utara, sehingga diperlukan upaya pemerintah setempat untuk lebih mengupayakannya.

\section{Kesimpulan}

Berdasarkan analisa dan kajian yang telah dilakukan pada bab sebelumnya, maka dapat ditarik beberapa kesimpulan sebagai berikut: 
1. Aceh utara merupakan salah satu penyumbang lumbung padi propinsi, bahkan nasional. Dengan jumlah produksi mencapai 235,776 ton/th dengan jumlah penduduk yang relative jarang, sehingga konsumsi beras dapat terpenuhi tiap tahunnya. Dampaknya aceh utara swasembada beras ke wilayah lainnya di luar propinsi aceh.

2. Luasnya wilayah lahan tidur, yaitu seluas $12,715 \mathrm{Ha}$, seandainya bisa dimaksimalkan pemanfaatannya mungkin masih banyak komoditas lain yang bisa dijadikan unggulan untuk meningkatkan taraf ekonomi masyarakatnya. Dibutuhkan peran serta semua elemen masyarakat dan pemerintah untuk mewujudkannya.

3. Minimnya pemanfaatan teknologi, terutama untuk pengairan mengakibatkan banyaknya lahan yang mengandalkan hujan sebagai pengairannya. Sehingga mengurangi produktifitas pertanian, selain itu teknologi tanam dan panen juga masih dilakukan secara manual.

4. Kurang maksimalnya pengolahan hasil bumi mengakibatkan nilai ekonomi yang minim, sebagai contoh, kakao dijual dalam bentuk mentah, tanpa pengolahan apapun, sehingga untuk mendapatkan hasil yang signifikan dibutuhkan volume produksi yang besar. Seandainya dapat diolah tentu akan menghasilkan nilai ekonomi yang lebih menguntungkan bagi masyarakat.

5. Penduduk aceh utara tersebar ke wilayah pesisir cukup signifikan dibandingkan perbukitan, ini juga merupakan faktor yang mengkibatkan banyaknya lahan tidur kurang maksimal pemanfaatannya. Hal ini bisa jadi dikarenakan keengganan masyarakat untuk tinggal diwilayah dataran tinggi, seperti perbukitan dan pegunungan.

Demikianlah beberapa kesimpulan yang dapat ditarik dari hasil kajian pada bab sebelumnya. Sedangkan untuk saran, paparannya adalah sebagai berikut :

1. Untuk pemerintah setempat, diharapkan untuk lebih proaktif dalam memaksimalkan pemanfaatan lahan tidur yang kurang produktif, misalkan dengan cara sesering mungkin melakukan penyuluhan dan pelatihan kepada masyarakat dalam hal memanfaatkan lahan yang belum terpakai.

2. Pengadaan bantuan alat pertanian yang tepat guna, agar masyarakat lebih termotivasi untuk mengolah lahan tidur. Kekurangan alat untuk mengolah lahan merupakan salah satu faktor keengganan masyarakat dalam pemanfaatan lahan ini.

3. Pembangunaan sentra - sentra hasil bumi, agar masyarakat lebih mudah dalam menjual dan memasarkan hasil - hasil pertanian mereka.

Semoga kesimpulan dan saran tersebut di atas dapan menjadi masukan bagi pihak terkait untuk ditindaklanjuti. Sehingga dapat menghasilkan dan produktif secara ekonomi, baik bagi pemerintah maupun masyarakatnya. Demi pembangunan Indonesia yang lebih maju, modern, mandiri dan produktif.

\section{Daftar Pustaka}

[1]Afiyanti, Y., 2005 Penggunaan Literatur Dalam Penelitian Kualitatif. Jurnal Keperawatan Indonesia, 32-35.

[2 ]Arsyad, K., 2017. Modul Studi Lapangan Pelatihan Pengendalian Banjir. Bandung: Kementerian PUPR dan BPSDM.

[3 ]Hamidi, 2015, Aplikasi Sistem Informasi Geografis Berbasis Web Penyebaran Dana Bantuan Operasional Sekolah . Jurnal Masyarakat Informatika, 40-49.

[4 ] Nursaidah, 2019, Aceh Utara Dalam Angka 2019. Aceh Utara: BPS Kabupaten Aceh Utara.

[5 ] Nursaidah, 2020, Kecamatan Baktiya Dalam Angka 2020. Aceh Utara: BPS Kabupaten Aceh Utara.

[6 ] Prahasta, E. (2000). Konsep-Konsep Dasar Sistem. Bandung: Informatika.

[7 ]Pressman, R. S.,1997, Software Engineering: A Practitioner's Approach. New York: The McGraw-Hill Companies. Inc.

[8 ]Riyanto, 2010, Sistem Informasi geografis berbasis online tahun 2010. Yogyakarta: Penerbit Gava Media Yogyakarta.

[9 ] https://acehutarakab.bps.go.id/pencarian.html?sear ching=peta+aceh+utara+\&yt1=Cari 